\title{
Efficiency of Local Exhaust Ventilation System during Stainless Steel Grinding
}

\author{
Miroslav Dado ${ }^{1}$, Marián Schwarz ${ }^{2}$, Alena Očkajová ${ }^{3}$, Richard Hnilica ${ }^{1}$, Daniela Borošová ${ }^{4}$ \\ ${ }^{1}$ Faculty of Environmental and Manufacturing Technology, Technical University in Zvolen. Studentska 26, 960 53 Zvo- \\ len. Slovak Republic. E-mail: dado@tuzvo.sk, hnilica@tuzvo.sk \\ ${ }^{2}$ Faculty of Ecology and Environmental Sciences, Technical University in Zvolen. T. G. Masaryka 24, 96053 Zvolen. \\ Slovak Republic. E-mail: schwarz@tuzvo.sk \\ ${ }^{3}$ Faculty of Natural Sciences, Matej Bel University. Tajovskeho 40, 97401 Banska Bystrica. Slovak Republic. E-mail: \\ alena.ockajova@umb.sk \\ ${ }^{4}$ Department of Chemical Analysis, Regional Authority of Public Health. Cesta k nemocnici 1, 97556 Banska Bystrica. \\ Slovak Republic. E-mail: daniela.borosova@vzbb.sk
}

In order to ensure acceptable level of risk associated with exposure to airborne dust they should have been mainly technical and organisation measures at workplaces with enhanced occurance of dust. Local exhaust ventilation (LEV) belongs to principal engineering control for prevention of airborne spreading. The aim of the study was to assess the efficiency of LEV system used at mechanical workshop for controlling respirable fraction of dust during stainless steel grinding activities. Dust control effectiveness was assessed by determining personal exposure levels with and without the use of LEV system. Personal dust samples were collected using a photometer-type dust monitor. On the basis of results it can be concluded that LEV system significantly improved quality of workplace atmosphere at given workplace.

Keywords: Stainless Steel, Grinding Dust, Local Exhaust Ventilation, Photometer

\section{Acknowledgement}

The authors wish to thank Mr. David Ked'úch for his participation in the study and Mrs. Lucia Mrózová for her skilful assistance in statistical analysis.

\section{References}

[1] BROSSEAU, L. M., LUNGU, C. T. (2005). The nature and properties of workplace airborne contaminants. In: Occupational Hygiene, $3^{\text {rd }}$ ed. (K. Gardiner, (Ed.)), pp. 85 - 104. Wiley-Blackwell, Oxford.

[2] CROSS, H. J., BEACH, L. S., SADHRA, S., SORAHAN, T., McROY, C. (1999). Manufacture, processing and use of stainless steel: a review of the health effects. EUROFER, Bruxelles.

[3] SANTONEN, T., STOCKMANN-JUVALA, H., ZITTING, A. (2010). Review on toxicity of stainless steel. Finish Institute of Occupational Health, Helsinki.

[4] SR Government Ordinance No. 355/2006 Coll. on protection of employees against risks due to to exposure to chemical factors at work as amended. In: Collection of Laws, Part 125, pp. 2550 - 2578. (in Slovak).

[5] JANKOWSKI, T. (2011). Impact of air distribution on efficency of dust capture from metal grinding - bench test method. In: Industrial Health, Vol. 49, No. 6, pp. 735 - 745.

[6] GLINSKI, M. (2002). Dust emission and effiency of local exhaust ventilation during cast iron grinding. In: International Journal of Occupational Safety and Ergonomics, Vol. 8, No. 1, pp. 95 - 105.

[7] CROTEAU, G. A., FLANAGAN, M. E., CAMP, J. E., SEIXAS, N. S. (2004). The efficacy of local exhaust ventilation for controlling dust exposures during concrete surface grinding. In: The Annals of Occupational Hygiene, Vol. 48, No. 6, pp. $509-518$.

[8] OJIMA, J. (2007). Efficiency of a tool-mounted local exhaust ventilation system for controlling dust exposure during metal grinding operations. In: Industrial Health, Vol. 45, No. 6, pp. 817 - 819.

[9] FLYNN, M. R., SUSI, P. Local exhaust ventilation for the control of welding fumes in the construction industry - a literature review. In: The Annals of Occupational Hygiene, Vol. 56, No. 7, pp. 764 - 776.

[10]LIVERSEED, D. R., LOGAN, P. W., JOHNSON, C. E., MOREY, S. Z., RAYNOR, P. C. (2013). Comparative emissions of random orbital sanding between conventional and self-generated vacuum systems. In: The Annals of Occupational Hygiene, Vol. 57, No. 2, pp. 221 - 229.

[11]ARMISHAW, P. (2003). Estimating measurement uncertainty in the afternoon. A case study in the practical application of measurement uncertainty. In: Accreditation and Quality Assurance, Vol. 8, Issue 5, pp. 218 - 224. 
[12]HOLEŠOVSKÝ, F., NÁPRSTKOVÁ, N., NOVÁK, M. (2012). GICS for grinding process optimization. In: Manufacturing Technology, Vol. 12, No. 12, pp. $22-26$.

[13]LUKÁČOVÁ, K., BADIDA, M., MORAVEC, M. (2011). Guidance for the assessment of exposure by inhalation to solid aerosols for comparison with limit value. In: Annals of Faculty of Engineering Hunedoar, Vol. 9, No. 2, pp. $141-144$.

[14]FRANSMAN, W., SCHINKEL, J., MEIJSTER, T., VAN HEMMEN, J., TIELEMANS, E., GOEDE, H. Development and evaluation of an exposure control efficacy library (ECEL). In: The Annals of Occupational Hygiene, Vol. 52, No. 7, pp. $567-575$.

Copyright @ 2 2016. Published by Manufacturing Technology. All rights reserved. 